\title{
SISTEM PERTANAHAN KERATON YOGYAKARTA SEBAGAI DAERAH OTONOMI KHUSUS
}

\author{
Shenita Dwiyansany ${ }^{*}$, Lita Tyesta Addy Listiya Wardhani2 \\ 1Fakultas Hukum, Universitas Kristen Satya Wacana \\ 2Fakultas Hukum, Universitas Diponegoro \\ shenitadwiyansany@gmail.com
}

\begin{abstract}
Indonesia is a Unitary State whose power is divided into regions through the granting of regional autonomy or giving authority to regions to administ and manage their own households through decentralization or through deconcentration. Yogyakarta in this case is an area that has specificity in the implementation of regional autonomy. The land system of the Yogyakarta palace is one of the features contained in the Yogyakarta regional regulations. The national land system with the customary land system in the Special Region of Yogyakarta is a system that cannot be equated. The granting of authority in special autonomy given to D.I.Y has important historical origin which cannot be separated from its customs.
\end{abstract}

Keywords: Regional Autonomy; Land; Special Autonomy; Special Region of Yogyakarta.

\begin{abstract}
ABSTRAK
Indonesia merupakan negara kesatuan yang kekuasaannya dibagi ke daerah-daerah melalui pemberian otonomi daerah atau pemberian wewenang kepada daerah-daerah untuk mengurus dan mengatur rumah tangganya sendiri melalui desentralisasi atau melalui dekonsentrasi. Yogyakarta dalam hal ini merupakan suatu daerah yang memiliki kekhususan dalam penyelenggaraan otonomi daerahnya. Sistem pertanahan keraton Yogyakarta merupakan salah satu keistimewaan yang terdapat dalam peraturan daerah Yogyakarta. Sistem pertanahan nasional dengan sistem pertanahan adat pada Daerah Istimewa Yogyakarta ini adalah merupakan sebuah sistem yang tidak dapat di persamakan. Metode penelitian bersifat yuridis normatif, dimana data yang diperoleh dianalisa secara kualitatif. Pemberian kewenangan dalam otonomi khusus yang diberikan kepada D.I.Y memiliki arti penting sejarah asal usul yang tidak dapat dipisahkan dari adat istiadatnya.
\end{abstract}

Kata Kunci: Otonomi daerah; Pertanahan; Otonomi Khusus; Daerah Istimewa Yogyakarta.

\footnotetext{
${ }^{*}$ Corresponding Author
} 
Jurnal Pembangunan Hukum Indonesia

Volume 1, Nomor 2, Tahun 2019
Program Studi Magister Ilmu Hukum Fakultas Hukum Universitas Diponegoro

\section{A. PENDAHULUAN}

Di dalam Undang Undang Nomor 5 Tahun 1960 tentang Peraturan Dasar Pokok Pokok Agraria (UUPA) Pasal 1 ayat (2) ; Seluruh bumi, air dan ruang angkasa, termasuk kekayaan alam yang terkandung didalamnya dalam wilayah Republik Indonesia sebagai karunia Tuhan Yang Maha Esa adalah bumi, air dan ruang angkasa bangsa Indonesia dan merupakan kekayaan nasional. UUPA dibuat dengan maksud untuk mengatur pemilikan tanah dan memimpin penggunaannya, sehingga semua tanah di seluruh wilayah kedaulatan bangsa dipergunakan untuk sebesar-besar kemakmuran rakyat, baik secara perseorangan maupun secara gotong-royong seperti cita cita pada Undang Undang Dasar 1945. Undang-Undang tersebut belum diterapkan secara penuh oleh beberapa daerah di Indonesia karena adanya daerah otonom khusus seperti Provinsi Daerah Istimewa Yogyakarta. Hal ini dikarenakan di daerah tersebut berlaku hukum nasional yakni UU No. 5 Tahun 1960 tentang Pokok Agraria dan hukum kerajaan atau Undang Undang Keistimewaan yang keduanya hingga kini masih eksis diberlakukan. Adanya dualisme hukum agraria tersebut menjadikan tanah-tanah yang berada di DIY sendiri menjadi tersekat-sekat antara tanah nasional, tanah penduduk, tanah Sultan (Sultan Ground), maupun tanah Pakualaman (Pakualaman Ground). (Jati, 2014).
Indonesia merupakan negara kesatuan, sebagaimana termaktub dalam UUD 1945 Pasal 1 ayat (1). Negara kesatuan adalah negara yang kekuasaannya dibagi ke daerah-daerah melalui pemberian otonomi daerah atau pemberian wewenang kepada daerah-daerah untuk mengurus dan mengatur rumah tangganya sendiri melalui desentralisasi atau melalui dekonsentrasi. Ini berarti bahwa daerah-daerah itu mendapatkan hak yang datang dari, atau diberikan oleh pemerintah pusat berdasarkan undang-undang dan konstitusi (Mahfud MD, 2012).

Melalui interpretasi gramatikal, pembagian satuan-satuan pemerintahan daerah dalam Negara Kesatuan Negara Republik Indonesia (NKRI) tersusun secara bertingkat (hierarki), antara daerah provinsi dan kabupaten/kota. Masing-masing satuan pemerintahan daerah, mengatur dan mengurus urusan pemerintahannya sendiri menurut asas otonomi daerah dan tugas pembantuan. Negara Kesatuan Republik Indonsia (NKRI) menganut prinsip otonomi seluas- luasnya dalam penyelenggaraan pemerintah daerah (Mahfud MD, 2012).

Daerah Istimewa Yogyakarta sebagai salah satu daerah yang mempunyai keistimewaan dalam melaksanakan pemerintahannya diatur melalui UU tersendiri, pada Agustus tahun 2012, Presiden Indonesia keenam, Susilo Bambang Yudhoyono, menutup polemik status Keistimewaan Daerah Istimewa Yogyakarta dengan menandatangani Undang-Undang No. 13 Tahun 
Jurnal Pembangunan Hukum Indonesia

Volume 1, Nomor 2, Tahun 2019
Program Studi Magister Ilmu Hukum Fakultas Hukum Universitas Diponegoro
2012 tentang daerah Keistimewaan. Keistimewaan tersebut didasarkan pada sejarah dan hak asal-usul Yogyakarta (Nurmandi \& Annafie, 2016). Kewenangan Istimewa tersebut diantaranya : a) tata cara pengisian jabatan, kedudukan, tugas dan wewenang Gubernur dan Wakil Gubernur, b) kelembagaan Pemerintah Daerah D.I. Yogyakarta, c) kebudayaan, d) pertanahan, dan e) tata ruang.

Salah satu kewenangan dari keistimewaan D.I. Yogyakarta ialah masalah pertanahan sebagaimana diatur dalam Undang-Undang No. 13 tahun 2012 tentang Keistimewaan Daerah Istimewa Yogyakarta. Pemerintah D.I. Yogyakarta berwenang mengatur bidang pertanahan, juga membuat peraturan pertanahan, khususnya dalam bidang perolehan hak atas tanah. Salah satu yang diatur adalah mengenai pembatasan perolehan hak milik atas tanah bagi Warga Negara Indonesia Non Pribumi. Di D.I..Y Warga Negara Indonesia Non Pribumi tidak dapat meperoleh hak atas tanah dengan Hak Milik seperti halnya dengan daerah lain.

Di Daerah Istimewa Yogyakarta tidak semua Warga Negara Indonesia dapat memperoleh Hak Milik seperti yang telah diatur dalam UUPA. Seakan-akan Pemerintah Derah memberikan pembedaan atau diskriminasi bagi Warga Negara Indonesia khususnya Warga Negara Indonesia Non Pribumi. Ditambah dengan adanya Instruksi Wagub D.I. Yogyakarta No K.898///A/1975 semakin menjadikan polemik pertanahan di D.I.

Yogyakarta yang menyatakan adanya tindakan deskriminatif dalam bidang pertanahan. Pembatasan pemberian Hak Milik tidak terlepas dari sejarah pemilikan tanah di D.I.. Yogyakarta. Sebagian besar tanah di daerah tersebut merupakan tanah milik Sultan dan Pakualam, merupakan tanah rakyat atau warga hanya dapat menempati atau mengelola tanah yang diberikan raja kepada rakyatnya. Tanah kerajaan yang diserahkan pada rakyat untuk dikelola itu disebut tanah Magersari.

Penelitian sebelumnya tentang tanah keraton membahas dan memaparkan konstruksi hak atas tanah keraton Yogyakarta berdasarkan komparasi sistem hukum tanah nasional dan sistem hukum tanah keraton Yogyakarta (Karjoko, 2006). Sistem pertanahan adalah pertentangan persepsi berkenaan dengan pemberlakuan hukum secara normative (Husni, 2011). Menurut Bambang Sadono, Sistem Pertanahan di Indonesia merupakan suatu bentuk legislasi yang sering dipolitisasi karena banyaknya peraturan yang sering bertentangan satu sama lain (Sadono, 2010). Suatu daerah yang memiliki otonomi khusus memiliki hambatan besar bagi daerah otonom yang menjalankan kekuasaan umum yang dicari orang Tibet dalam rangka melestarikan budaya, nilai- nilai dan identitas mereka (Woodman, 2010). Hak katas tanah merupakan privilege yang dimiliki oleh masyarakat. Oleh karena itu pengabaian hak atas tanah yang dimiliki masyarakat memiliki dampak yang 
negatif, dan hal tersebut seringkali dimanfaatkan oleh Pemerintah Daerah (Duncan, 2007).

Tulisan ini akan mengkaji lebih dalam mengenai sistem pertanahan nasional dalam daerah otonomi khusus (Daerah Istimewa Yogyakarta), dan juga melihat lebih lanjut mengenai aturan larangan atas hak milik tanah bagi warga negara non pribumi jika dilihat dari hak istimewa D.I. Yogyakarta.

\section{B. METODE PENELITIAN}

Metode penelitian bersifat yuridis normatif. Data yang digunakan merupakan data primer yang diperoleh dari kepustakaan maupun penelitian lapangan (field research), dan data sekunder untuk menunjang data primer yang berasal dari bahan hukum primer, sekunder dan tersier. Selanjutnya data-data tersebut dianalisis secara kualitatif guna mendapatkan jawaban atas permasalahan dalam penelitian

\section{HASIL DAN PEMBAHASAN}

\section{Sistem Pertanahan Nasional Dalam Daerah Otonomi Khusus (Daerah Istimewa Yogyakarta)}

Secara yuridis, Pemerintahan Daerah Istimewa Yogyakarta dibentuk secara legal formal berdasarkan UU Nomor 14 Tahun 2012 tentang Keistimewaan Daerah Istimewa Yogyakarta setelah melalui beberapa kali perubahan Undang-Undang. Keistimewaan D.I.Y ini didasari atas sejarah kesultanan yang sejak dahulu turun temurun dibudidayakan. Kewenangan khusus dari
Pemerintahan D.I.Y. ini tercantum pada UndangUndang Keistimewaan Daerah Istimewa Yogyakarta yang dalam hal ini urusan keistimewaan kewenangan Pemerintahan DIY meliputi : tata cara pengisian jabatan, kedudukan, tugas dan wewenang gubernur dan wakil gubernur, kelembagaan pemerintah daerah, kebudayaan, pertanahan dan tata ruang, yang mana penyelenggaraan kewenangan dalam urusan keistimewaan tersebut didasarkan pada nilai-nilai kearifan lokal dan keberpihakan.

Dasar pemikiran yang melatarbelakangi pemberian status keistimewaan bagi Provinsi Daerah Istimewa Yogyakarta yaitu, status istimewa yang melekat pada DIY merupakan bagian integral dalam sejarah pendirian negara-bangsa Indonesia; masyarakat Yogyakarta yang homogen pada awal kemerdekaan meleburkan diri ke dalam masyarakat Indonesia yang majemuk, baik etnik, agama maupun adat istiadat; setelah Proklamasi 17 Agustus 1945, Sultan Hamengku Buwono IX dan Adipati Paku Alam VIII memutuskan untuk menjadi bagian dari Indonesia; peran Yogyakarta terus berlanjut di era revolusi kemerdekaan yang diwujudkan melalui upaya Kesultanan dan Kadipaten serta rakyat Yogyakarta dalam mempertahankan, mengisi, dan menjaga keutuhan Negara Kesatuan Republik Indonesia; Kasultanan dan Kadipaten tetap diposisikan sebagai simbol pengayom kehidupan masyarakat dan tetap sebagai ciri keistimewaan DIY; dan pengaturan Keistimewaan D I Y bertujuan untuk 
Jurnal Pembangunan Hukum Indonesia

Volume 1, Nomor 2, Tahun 2019
Program Studi Magister Ilmu Hukum Fakultas Hukum Universitas Diponegoro mewujudkan tata pemerintahan yang baik dan demokratis, ketenteraman dan kesejahteraan masyarakat, menjamin ke-bhinneka tunggal-ika-an, dan melembagakan peran dan tanggung jawab Kasultanan dan Kadipaten dalam menjaga dan mengembangkan budaya Yogyakarta yang merupakan warisan budaya bangsa (Baharudi, 2016).

Tujuan pemberian otonomi daerah adalah sebagai berikut (Baharudi, 2016); a) peningkatan pelayanan masyarakat semakin baik, b) pengembangan kehidupan demokrasi, c) keadilan nasional, d) pemerataan wilayah daerah pemeliharaan hubungan yang serasi antara pusat dan daerah serta antar daerah dalam rangka keutuhan NKRI, e) mendorong pemberdayaan masyarakat, menumbuhkan prakarsa dan kreatifitas, meningkatkan peran serta masyarakat, mengembangkan peran dan fungsi DPRD.

Daerah Istimewa Yogyakarta sebagai daerah otonomi khusus juga mempunyai Undang-Undang Keistimewaan Daerah Istimewa Yogyakarta yang berwenang atas 5 (lima) urusan keistimewaan meliputi ; tata cara pengisian jabatan, kedudukan, tugas,dan wewenang gubernur dan wakil gubernur; kelembagaan pemerintah DIY; kebudayaan; pertanahan; dan tata ruang seperti yang dicantumkan dalam Pasal 7 ayat (2) UU Keistimewaan DIY. Adanya pasal dan keistimewaan tersebut Kasultanan dan Kadipaten Pakualaman menjadi badan hukum yang merupakan subyek pemilik hak atas tanah
Kasultanan dan tanah Kadipaten Pakualaman yang berwenang untuk mengelola dan memanfatkannya baik yang berupa tanah keprabon dan bukan tanah keprabon yang terdapat di seluruh wilayah Daerah Istimewa Yogyakarta. Pada Pasal 33 ayat (4) UU Keistimewaan DIY mengatur dan menjelaskan bahwa pengelolaan dan pemanfaatan atas tanah tanah tersebut oleh perseorangan, badan hukum, badan usaha, maupun badan sosial harus mendapat ijin dari Kasultanan untuk tanah Kasultanan ataupun Kadipaten Pakualaman untuk tanah Pakualaman, hak milik tanah tanah adat ini masih menjadi hak milik atau merupakan domain bebas dari Kasultanan Yogyakarta-Kadipaten Paku Alaman dan hingga kini belum terjangkau ketentuan ketentuan UUPA karena dalam pengaturan penguasaan tanah hanya diatur beberapa konversi perorangan bekas hak adat menjadi hak milik saja, sedangkan untuk Tanah Lembaga Keraton Kasultanan Sultan G round (SG) dan tanah Lembaga Kadipaten Pakualaman Paku Alam Ground (PAG) belum diterapkan konversinya dalam sistem hukum tanah nasional (Munsyarief, 2013).

Konsepsi hukum pertanahan nasional yang dimiliki oleh NKRI setelah lahirnya UUPA adalah konsepsi komunalistik religious, sehingga konsep tanah feodal juga tidak sesuai dengan semangat kepemilikan bersama tanah bangsa Indonesia sebagai karunia Tuhan yang Maha Esa. Konsepsi tanah feodal adalah konsepsi yang menyatakan hak penguasaan tanah yang terdapat diseluruh wilyah 
Jurnal Pembangunan Hukum Indonesia

Volume 1, Nomor 2, Tahun 2019
Program Studi Magister Ilmu Hukum Fakultas Hukum Universitas Diponegoro kekuasaan raja adalah milik raja yang bersangkutan (Darme, \& Ayu, 2016). Artinya, klaim atas tanah-tanah Sultanaat Ground (SG) dan Pakualaman Ground (PAG) tidak mempunyai dasar hukum yang sah, karena SG/PAG termasuk tanah swapraja (feodal) yang sudah dihapuskan oleh Diktum IV UUPA. Di samping itu, Undang-Undang Keistimewaan D.I Yogyakarta juga melarang penghidupan kembali feodalisme (Pasal 4) dan penyalahgunaan wewenang oleh Gubernur (Pasal 16). UUPA sebagai aturan khusus dari UUD 1945 Pasal 33 ayat (3) adalah dasar hukum yang mengatur pertanahan di DIY saat ini. Bahkan, pemberlakuan kembali Rijksblad 1918 (aturan pemerintah kolonial) dalam tata hukum NKRI adalah anomali hukum. SG/PAG sudah dihapuskan oleh HB IX, PA VIII, beserta DPRD melalui Perda DIY No 3 Tahun 1984 yang merupakan pelaksanaan dari Keputusan Presiden No 33 Tahun 1984 dan UUPA (Rahmahsari, 2016).

Pengaturan hak atas tanah keraton Yogyakarta berkaitan dengan konsep kerajaan Jawa : Sultan adalah sumber satu-satunya dari segenap kekuatan dan kekuasaan dan dialah pemilik segala sesuatu termasuk tanah di dalam kerajaan, dan karena itu dia diidentikkan dengan kerajaan. Kehormatan, prestis, keadilan dan kekuasaan, kebijaksanaan dan kemakmuran semua terletak padanya. Ada pembedaan yang tajam antara pemerintahan pada lingkaran dalam atau lingkaran pertama, yakni keraton, dengan ketiga lingkaran di luarnya, yakni nagara, nagaragung dan mancanagara (Soemardjan, 1991).

Hak menguasai dari negara diatur dalam Pasal

2 UUPA yang berbunyi sebagai berikut :

"a) Atas dasar ketentuan dalam Pasal 33 ayat (3) Undang-Undang Dasar dan hal-hal sebagai yang dimaksud dalam Pasal 1, bumi, air dan ruang angkasa, termasuk kekayaan alam yang terkandung di dalamnya itu, pada tingkatan tertinggi dikuasai oleh negara sebagai organisasai seluruh rakyat;

b) Hak menguasai dari negara termaksud dalam ayat

(1) pasal ini memberi wewenang untuk:

(1) mengatur dan menyelenggarakan peruntukan, penggunaan, persediaan dan pemeliharaan bumi, air dan ruang angkasa tersebut;

(2) menentukan dan mengatur hubungan-hubungan hukum antara orang-orang dengan bumi, air dan ruang angkasa;

(3) menentukan dan mengatur hubungan-hubungan hukum antara orang-orang dan perbuatanperbuatan hukum yang mengenai bumi, air dan ruang angkasa.

c) Wewenang yang bersumber pada hak menguasai dari negara tersebut pada ayat (2) pasal ini, digunakan untuk mencapai sebesar-besar kemakmuran rakyat, dalam arti kebangsaan, kesejahteraan dan kemerdekaan dalam masyarakat dan negara hukum Indonesia yang merdeka, berdaulat, adil dan makmur;

d) Hak menguasai dari negara tersebut di atas pelaksanaannya dapat dikuasakan kepada daerahdaerah swatantra dan masyarakat-masyarakat hukum adat, sekedar diperlukan dan tidak bertentangan dengan kepentingan nasional, menurut ketentuan-ketentuan Peraturan Pemerintah".

Negara sebagai organisasi kekuasaan "mengatur" sehingga membuat peraturan, kemudian "menyelenggarakan" artinya melaksanakan, atas 
Jurnal Pembangunan Hukum Indonesia

Volume 1, Nomor 2, Tahun 2019
Program Studi Magister Ilmu Hukum Fakultas Hukum Universitas Diponegoro penggunaan/peruntukan, persediaan dan pemeliharaannya dari bumi, air, ruang angkasa dan kekayaan alam yang terkadung di dalamnya. Juga untuk menentukan dan mengatur (menetapkan dan membuat peraturan-peraturan) hak-hak apa saja yang dapat dikembangkan dari hak menguasai dari negara tersebut. Kemudian menentukan dan mengatur (menetapkan dan membuat peraturanperaturan) bagaimana seharusnya hubunga antara orang atau badan hukum dengan bumi, air dan ruang angkasa dan kekayaan alam yang terkandung didalamnya (Karjoko, 2006).

Sistem pemerintahan Kasultanan Yogyakarta dijalankan dengan membentuk suatu sistem satuansatuan administratif yang sangat otonom sifatnya dan swasembada dalam keuangannya. Dengan demikian urusan pertanahan dilaksanakan oleh Pemerintah provinsi DIY. Hal ini sejalan dengan pendapat Bagir Manan mengenai perlunya desentralisasi. Pertama sebagai cerminan dari ciri kerakyatan yang mengedepankan sikap arif bijaksana dalam memecahkan segala sesuatu secara musyawarah. Musyawarah dilakukan sebagai wujud keikutsertaan rakyat dalam penyelenggaraan pemerintahan di tingkat daerah dengan memberi wewenang, tugas dan tanggung jawab untuk mengatur dan mengurus kepentingan-kepentingan rumah tangganya daerah sendiri dengan secara bebas melakukan berbagai prakarsa (inisiatif) dalam batasbatas ketentuan yang berlaku. Kedua,untuk lebih memberikan penghargaan atas pemerintahan asli yang telah ada sejak dahulu baik dalam bentuk pemerintah otonom. Oleh karena itu, hubungan kausalitas antara sistem pertanahan nasional dengan sistem pertanahan pada Daerah Istimewa Yogyakarta ini adalah merupakan sebuah sistem yang tidak dapat dipersamakan, mengingat kekhususan yang dimiliki D.I..Y ini merupakan arti penting sejarah asal usul, jadi hukum nasional pun menghendaki dan menghargai kebijakan tersebut untuk daerah Yogyakarta ini dengan memberikan otonomi khusus.

\section{Aturan Larangan Atas Hak Milik Tanah Bagi Warga Negara Non Pribumi J ika Dilihat Dari Hak Istimewa D.I. Yogyakarta.}

Masalah pertanahan di D.I Yogyakarta sampai saat ini masih menjadi perdebatan antara adanya tindakan diskriminasi terhadap WNI keturunan, hal ini didasarkan pada Instruksi Kepala daerah D.I Yogyakarta Nomor K.898///A/1975 perihal penyeragaman policy pemberian Hak atas Tanah bagi seorang WNI keturunan atau non pribumi. Instruksi ini terbit pada tanggal 5 Maret 1975 dan ditandatangani oleh Wakil Kepala Daerah D.I Yogyakarta saat itu, Paku Alam VIII. Dalam instruksi tersebut dinyatakan, Pemerintah D.I Yogyakarta belum memberikan hak milik atas tanah kepada warga negara Indonesia non pribumi.

Berdasarkan pada putusan Mahkamah Agung No. 13P/HUM/ 2015, instruksi tersebut bukan 
Jurnal Pembangunan Hukum Indonesia

Volume 1, Nomor 2, Tahun 2019
Program Studi Magister Ilmu Hukum Fakultas Hukum Universitas Diponegoro termasuk kedalam peraturan perundang-undangan. Selain itu tidak ada undang-undang atau aturan pertanahan dari BPN yang menjadikan instruksi Nomor K.898///A/1975 tersebut sebagai rujukan, sehingga tidak bisa dijadikan dasar untuk menolak permohonan penerbitan SHM oleh warga keturunan / non pribumi. Oktober 2017, Handoko (35) salah satu warga D.I Yogyakarta keturunan Tionghoa menggugat Gubernur D.I Yogyakarta Sultan Hamenku Buwono $X$ dan Pejabat Kepala kantor Badan Pertanahan Masional (BPN) D.I Yogyakarta. Gugatan diajukan karena kedua pihak dinilai menjalankan instruksi Nomor K.898/I/A/1975. Penggugat menilai, bahwa intruksi tersebut bertentangan dengan Undang-Undang No. 5 Tahun 1960 tentang Peraturan Dasar Pokok-Pokok Agraria serta Intruksi Presiden Nomor 1998 yang melarang penggunaan istilah pribumi-dan non pribumi dalam perumusan dan penyelenggaraan kebijakan (Handoko, 2018).

Atas Gugatan tersebut, Hakim Pengadilan Negeri Yogyakarta menolak gugatan yang mempersoalkan kebijakan diskriminasi pertanahan oleh Pemerintah Daerah Istimewa Yogyakarta. Majelis Hakim menilai kebijakan melarang warga etnis Tionghoa memilik tanah di D.I Yogyakarta bukanlah tindakan melawan hukum. Dalam putusannya majelis Hakim yang diketuai oleh Cokro Hendro Mukti dengan Hakim anggota Sri Harsiwi dan Nuryanto menyebutkan, Pemerintah D.I Yogyakarta memiliki kewenangan istimewa untuk mengatur kebijakan dan peraturan terkait pertanahan dan tata ruang. Keistimewaan ini secara tegas memberikan kewenangan kepada Pemerintah D.I Yogyakarta dibidang pertanahan dalam rangka menjaga sejarah dan kebudayaan, khususnya keberadaan Kesultanan Ngayogyakarta. Putusan didasarkan pada keterangan saksi ahli dalam persidangan, yaitu instruksi yang selama ini menjadi pedoman kebijakan pertanahan di D.I Yogyakarta bukan produk perundang-undangan, sehingga tidak bisa diuji dengan produk perundangundangan lain yang lebih tinggi. Instruksi ini hanya produk kebijakan umum yang hanya dapat diuji dengan asas umum pemerintahan yang baik (Kusuma, 2018).

Berbeda halnya dengan Ombudsman selaku badan yang berfungsi mengawasi penyelenggaraan Pelayanan Publik baik di pusat maupun daerah. Ombudsman Perwakilan Daerah D.I Yogyakarta meminta kebijakan yang melarang warga non pribumi memiliki tanah di D.I Yogyakarta tidak lagi diberlakukan. Ombudsman menilai, keputusan beberapa kantor pertanahan di D.I Yogyakarta yang menolak penerbitan sertifikat hak milik tanah untuk warga keturunan Tionghoa merupakan tindakan malaadministrasi. Adanya tindakan mala-administrasi terungkap dalam dokumen Hasil Akhir Pemeriksaan Laporan Ombudsman perwakilan D.I Yogyakarta dalam hal pelayanan peralihan Hak Milik atas Tanah oleh Kepala Kantor Pertanahan Kabupaten Bantul, Kabupaten Kulon Progo dan Kota Yoryakarta (Handoko, 2018). 
Jurnal Pembangunan Hukum Indonesia

Volume 1, Nomor 2, Tahun 2019
Program Studi Magister Ilmu Hukum Fakultas Hukum Universitas Diponegoro
Mengenai isu diskriminasi bagi WNI keturunan di D.I Yogyakarta mengenai Hak Milik atas Tanah masih menjadi perdebatan, jika dilihat dari sisi UUPA dan HAM tentu adanya bentuk diskriminasi karena ada pembedaan antara WNI pribumi dan non pribumi, namun hal ini dipatut dikembalikan lagi kedalam aturan mengenai Keistimewaan D.I Yogyakarta yang mempunyai sejarah panjang dan hak asal usul, terutama dalam bidang pertanahannya.

Pakar Hukum Agraria Universitas Gadjah Mada Nur Hasan Ismail dan pakar Hukum Tata Negara Universitas Islam Indonesia (UII) Ni'matul Huda menyebutkan, instruksi Nomor K.898/I/A/1975 ini merupakan bentuk diskrimnasi dan penyeragaman Kebijakan Pemberian Hak atas Tanah kepada Seorang WNI non pribumi dinilai sudah tidak relevan lagi, Ni'matul Huda, menyarankan untuk mengubah instruksi diskriminatif itu menjadi Perda agar WNI non pribumi dapat memperoleh haknya. Ni'matul beralasan dengan membuat Perda, WNI non pribumi dapat mengajukan uji materi kepada MA. Instruksi tersebut tidak bisa dibawa ke Mahkamah Agung karena pada dasarnya instruksi tersebut bukan peraturan perundang- undangan.

Pengaturan tanah D.I Yogyakarta merupakan proses sejarah panjang yang awalnya dimaksudkan untuk mensejahterakan masyarakat supaya tidak ada ketimpangan, maka tidak salah seorang Kepala Daerah melestarikan ketentuan hukum adatnya, serta adanya UUD 1945 Pasal 18 b ayat 1 dan 2 tentang daerah khusus dan istimewa serta masyarakat hukum adat serta hak-hak tradisionalnya dan hingga lahirlah UU tentang Keistimewaan D.I Yogyakarta sebagai suatu pengakuan. Pada dasarnya memang ada bentuk diskriminasi namun tidak ada bentuk pelanggaran HAM dari kebijakan tersebut, dalam konvensi HAM internasional yang diratifikasi oleh pemerintah Indonesia diatur deskriminasi positif, dimana deskriminasi positif boleh dilakukan jika itu tujuannya baik. Pemberlakuan deskriminasi positif untuk mengilangkan deskriminasi yang sudah ada, yaitu penderitaan masyarakat Indonesia. Sebagai contoh masih tingginya ketimpangan antara si kaya dan si miskin di D.I Yogyakarta, sehingga pemerintah D.I Yogyakarta membuat suatu kebijakan mengenai hak kepemilikan tanah, dimana tanah lebih diperuntukkan untuk kesejahteraan masyarakat D.I Yogyakarta. Disamping itu, yang perlu digaris bawahi, kebijakan tersebut tidak hanya dimaksudkan untuk masyarakat keturunan Tionghoa semata, karena dalam kebijakanhanya disebutkan kata non pribumi.

\section{SIMPULAN}

Hubungan kausalitas antara sistem pertanahan nasional dengan sistem pertanahan adat pada Daerah Istimewa Yogyakarta ini adalah merupakan sebuah sistem yang tidak dapat di persamakan, mengingat kekhususan yang dimiliki D.I.Y ini merupakan arti penting sejarah asal usul, jadi hukum nasional pun menghendaki dan menghargai kebijakan tersebut 
Jurnal Pembangunan Hukum Indonesia

Volume 1, Nomor 2, Tahun 2019

untuk daerah Yogyakarta ini dengan memberikan otonomi khusus.

Negara Kesatuan Republik Indonesia adalah negara yang kekuasaannya dibagi ke daerah-daerah melalui pemberian otonomi daerah atau pemberian wewenang kepada daerah-daerah untuk mengurus dan mengatur rumah tangganya sendiri melalui desentralisasi atau melalui dekonsentrasi. D.I.Yogyakarta sebagai daerah yang diberikan wewenang otonomi khusus ini diharapkan mampu mengurus sendiri kebutuhan rumah tangganya, termasuk dalam hal pertanahan. Polemik mengenai peraturan pertanahan nasional dengan peraturan pertanahan di D.I.Yogyakarta ini memberikan makna bahwa diberikannya otonomi khusus kepada D.I.Yogyakarta karena pertanahan di daerah tersebut memiliki makna sejarah atau asal usul yang tidak dapat dipisahkan dari adat istiadatnya.

\section{DAFTAR PUSTAKA}

\section{BUKU}

Mahfud MD, M. (2012). Membangun Politik Hukum, Menegakkan Konstitusi. Jakarta: PT. Raja Grafindo.

Munsyarief. (2013). Menuju Kepastian Hukum Atas

Tanah: Kasultanan Dan Pakualaman di Daerah

Istimewa Yogyakarta. Yogyakarta: CV. Ombak.

Soemardjan, S. (1991). Perubahan Sosial di

Yogyakarta. Yogyakarta: Gadjah Mada University Press.
Program Studi Magister Ilmu Hukum Fakultas Hukum Universitas Diponegoro

\section{J URNAL}

Darme, Made., \& Ayu, I Gusti. (2016). Kebijakan Pertanahan Daerah Istimewa Yogyakarta Dalam Konsep Negara Kesatuan Republik Indonesia, e-Jurnal, Jurnal Pasca Sarjana Hukum UNS, Vol. IV, No. 2, Juli- Desember, p.112.

Baharudi. (2016). Desain Daerah Khusus/ Istimewa Dalam Sistem Negara Kesatuan Republik Indonesia Menurut Konstitusi. Jurnal MasalahMasalah Hukum, Jilid 45 No. 2, p.87.

Husni, A. (2011). Hak-Hak Kolektif Dalam Sistem Hukum Pertanahan (Studi Analisis Mengenai Fungsi Hukum Dalam Konflik Pertanahan). Jurnal Masalah-Masalah Hukum, Vol.40, (No.4), p.419.

Karjoko, L. (2006). Komparasi Sistem Hukum Tanah Nasional dengan Sistem Hukum Tanah Keraton Yogyakarta. Jurnal Yustitia, Edisi No. 68, Mei, pp. 58-59.

Nurmandi, Achmad., \& Annafie, Khotman. (2016). Kelembagaan Otonomi Khusus (OtSus) Dalam Mempertahankan Nilai-Nilai Kebudayaan Di Provinsi Daerah Istimewa Yogyakarta. Jurnal Ilmu Pemerintahan dan Kebijakan Publik, Vol.3 (No. 2, Juni), p.305.

Rahmahsari, Novi. A. (2016). Implikasi Lahirnya Undang-Undang Nomor 13 Tahun 2012 tentang Keistimewaan Daerah Istimewa Yogyakarta terhadap Status Hukum Pakualaman Ground di 
Kabupaten Kulon Progo. Lex Reinaissance

J ournal, Vol.1, (No.2, Juli), p. 99.

Sadono, B. (2010). Politisasi Hak Pengelolaan (HPL) Dalam Sistem Hukum Pertanahan Nasional. J urnal Masalah-Masalah Hukum, Vol.39, (No.4), p. 372.

Jati, Wasisto R. (2014). Politik Agraria Di Yogyakarta :Identitas Partrimonial \& Dualisme Hukum Agraria. J urnal Legislasi Indonesia, Vol.11, (No.1), pp. 25-37.

Duncan, Christhoper R. (2007). Mixed Outcomes: The Impact of Regional Autonomy and Decentralization on Indigenous Ethnic Minorities in Indonesia. Development And Change, Vol.38, Issue 4, pp.711-733.

Woodman, S. (2010). Is There Space For "Genuine Autonomy" For Tibetan Areas in The PRC's System of Nationalities Regional Autonomy. International J ournal on Minority and Group Rights, Vol.17, Issue 1, pp.137186.

\section{SUMBER ONLINE}

Handoko. (2018). Hapus Diskriminasi DIY. Retireved from Kompas.com.

Kusuma, W. (2018). Pertanahan Daerah Istimewa Yogyakarta,Warga Keturunan Tak Bisa Memiliki. Retrieved from Kompas.com. 